\title{
Ethanol Root-extract of Sphenocentrum jollyanum Restored Altered Haematological Markers in Plasmodium berghei-infected Mice
}

\author{
E. U. Ekpono*, P. M. Aja, U. A. Ibiam, E. U. Alum and U. E. Ekpono \\ Department of Biochemistry, Faculty of Science, Ebonyi State University, Abakaliki, Nigeria \\ e-mail: ekponoezebuilo@gmail.com \\ *Corresponding author
}

\section{Abstract}

\begin{abstract}
Effect of ethanol root-extract of Sphenocentrum jollyanum on some haematological parameters in Plasmodium berghei-infected mice was carried out using a total of thirtysix albino mice. The mice were randomly assigned into six experimental groups of A-F with six mice in each group. Mice in group A (Normal control) were administered with normal saline. Mice in groups B-F were infected with Plasmodium berghei intraperitoneally. Mice in group B (Positive control) were treated with $5 \mathrm{mg} / \mathrm{Kg}$ body weight of standard drug; mice in group $\mathrm{C}$ (Negative control) were left without treatment while mice in groups D, E and F were treated with graded doses of 200, 400 and 800 $\mathrm{mg} / \mathrm{Kg}$ body weight of the ethanol root extract of Sphenocentrum jollyanum, respectively. All the mice were allowed access to water and feed without restriction. Oral route was used for the administration of the standard drug and plant extract. The treatment lasted for ten days. Percentage parasitaemia was determined on the 3rd day and last day after infection. Evaluations of haematological parameters were done using spectrophotometric method while percentage parasitaemia count was done using microscopic method. Treatment of the infected mice with the ethanol root extract of Sphenocentrum jollyanum reduced parasite count significantly $(\mathrm{P}<0.05)$. Infection of mice with Plasmodium berghei caused a significant $(\mathrm{P}<0.05)$ decrease in the levels of pack cell volume $(\mathrm{PCV})$, haemoglobin (HB), red blood cell (RBC) and white blood cell (WBC) count relative to the normal control. However, treatment of P.berghei-infected mice with the ethanol root
\end{abstract}

\section{Received: June 3, 2019; Accepted: July 27, 2019}

Keywords and phrases: haematology, Plasmodium berghei, mice, Sphenocentrum jollyanum, root-extract.

Copyright (C) 2019 E. U. Ekpono et al. This is an open access article distributed under the Creative Commons Attribution License, which permits unrestricted use, distribution, and reproduction in any medium, provided the original work is properly cited. 
extract of Sphenocentrum jollyanum at the doses of 200,400 and $800 \mathrm{mg} / \mathrm{Kg}$ body weight of the mice showed a dose-dependent significant $(\mathrm{P}<0.05)$ reversal in the trend of these parameters to a level comparable to that observed among the standard control group, especially, the highest dose of $800 \mathrm{mg} / \mathrm{Kg}$ body weight. This study indicates that ethanol root extract of Sphenocentrum jollyanum could be used in the management of anaemic diseases associated with Plasmodium berghei infection.

\section{Introduction}

Hematology refers to the study of the numbers and morphology of the cellular elements of the blood. These elements include: packed cell volume, haemoglobin, red blood cells (erythrocytes), white cells (leucocytes), and the platelets (thrombocytes) and the use of these results in the diagnosis and monitoring of disease (Merck [2]). Haematological studies are useful in the diagnosis of many blood related diseases as well as investigation of the extent of damage to blood since constituents change in relation to the physiological conditions of health (Olafedehan et al. [3]). Blood act as a pathological reflector of the status of exposed animals to toxicant and other conditions (Olafedehan et al. [3]). Animals with good blood composition are likely to show good performance (Isaac et al. [4]).

Plasmodium berghei infectious diseases affect one or more cellular lineages of the hematologic system, and thus frequent hematologic manifestations, such as anemia, neutropenia, thrombocytopenia, and hematologic malignancies, are observed in these diseases. These hematologic abnormalities are due to several immune- and non-immunemediated mechanisms. The causes of haematological abnormalities are excessive production of cytokines, antibodies, immune complexes, growth factor deficiencies, increased peripheral accumulation, decreased neutrophil functions, gastrointestinal losses, and medication-related toxicities (Qin et al. [5], Soydinc et al. [6]).

The haematocrit (Ht or HCT) or packed cell volume (PCV) or erythrocyte volume fraction $(E V F)$ is the proportion of blood volume that is occupied by red blood cells (Mason [7]). It is normally about $46 \%$ for men and 38\% for women (Purves et al. [9]). In cases of dengue fever, where the full blood count is done daily, a high haematocrit is a danger sign of an increased risk of dengue shock syndrome (Mason [7]). Polycythaemia Vera (PV) is associated with elevated haematocrit. Chronic obstructive pulmonary disease (COPD) and other pulmonary conditions associated with hypoxia may elicit an increased production of red blood cells. This increase is mediated by the increased levels 
of erythropoietin by the kidneys in response to hypoxia. Professional athletes' haematocrit levels are measured as part of tests for blood doping or Erythropoietin (EPO) use; the level of haematocrit in a blood sample is compared with the long-term level for that athlete (to allow for individual variations in haematocrit level) and against an absolute permitted maximum (which is based on maximum expected levels within the population and the haematocrit level which causes increased risk of blood clots resulting in strokes or heart attacks) (Purves et al. [9]). If a patient is dehydrated, the haematocrit may be elevated. Repeated testing after adequate hydration therapy will usually result in a more reliable result. Lowered haematocrit can imply significant hemorrhage (for example, in an ectopic pregnancy) (Purves et al. [9]). A low haematocrit with a low MCV with a normal RDW suggests a chronic iron-deficient erythropoiesis, but a high RDW suggests a blood loss that is more acute, such as a hemorrhage (Purves et al. [9]). Groups of individuals who are at risk for developing anemia include: infants who may not have adequate iron intake, children going through a rapid growth spurt, during which the iron available cannot keep up with the demands for a growing red cell mass, women in childbearing years who have an excessive need for iron because of blood loss during menstruation, pregnant women, in whom the growing fetus creates a high demand for iron and patients with chronic kidney disease, as their kidneys no longer secrete sufficient levels of the hormone erythropoietin which stimulates red blood cell production by the bone marrow (Purves et al. [9]).

White blood cells or leukocytes are cells of the immune system defending the body against both infectious disease and foreign materials. Several different and diverse types of leukocytes exist, but they are all produced and derived from a multipotent cell in the bone marrow known as hematopoietic stem cell (Maton et al. [8]). The number of leukocytes in the blood is often an indicator of disease. There are normally between $4 \times 10^{9}$ and $11 \times 10^{9}$ white blood cells in a litre of blood, making up approximately $1 \%$ of blood in a healthy adult (Bruce [10]). In conditions such as leukemia, the number of leukocytes is higher than normal, and in leukopenia, this number is much lower. The physical properties of leukocytes, such as volume, conductivity and granularity, may change due to activation, the presence of immature cells or the presence of malignant leukocytes in leukemia (Bruce [10]).

Haemoglobin also spelled hemoglobin is the iron-containing oxygen-transport metalloprotein in the red blood cells of vertebrates (Maton et al. [8]). In mammals, the protein makes up about $97 \%$ of the red cell's dry content and around 35\% of the total 
content (including water) (Maton et al. [8]). Hemoglobin transports oxygen from the lungs or gills to the rest of the body, such as the muscles, where it releases the oxygen for cell use. It also has a variety of other roles of gas transport and effect-modulation which vary from species to species and are quite diverse in some invertebrates (Maton et al. [8]). Haemoglobin concentration measurement is among the most commonly performed blood tests, usually as part of a complete blood count. For example it is typically tested before blood donation. Normal levels includes: men: 13.5 to $16.5 \mathrm{~g} / \mathrm{dl}$, women: 12.1 to $15.1 \mathrm{~g} / \mathrm{dl}$, children: 11 to $16 \mathrm{~g} / \mathrm{dl}$ and pregnant women: 11 to $12 \mathrm{~g} / \mathrm{dl}$ (Maton et al. [8]). If the concentration is below normal, this is called anemia (Range et al. [11]).

Red blood cells (RBCs), also called erythrocytes, are the most common type of blood cell and the vertebrate organism's principal means of delivering oxygen $\left(\mathrm{O}_{2}\right)$ to the body tissues - via blood flow through the circulatory system (Pierigè et al. [12]). RBCs take up oxygen in the lungs or gills and release it into tissues while squeezing through the body's capillaries. The cytoplasm of erythrocytes is rich in hemoglobin, an ironcontaining biomolecule that can bind oxygen and is responsible for the red color of the cells (Pierigè et al. [12]). The cell membrane is composed of proteins and lipids, and this structure provides properties essential for physiological cell function such as deformability and stability while traversing the circulatory system and specifically the capillary network (Pierigè et al. [12]).

Sphenocentrum jollyanum is one of the well known medicinal plants with an erect, small, evergreen, dioecious shrub up to $1.5 \mathrm{~m}$ tall, sparingly branched; roots bright yellow; stem thinly short-hairy when young, later glabrous; bark grey (Nia et al. [13]). It is called "Ezeogwu" in Igbo, "Akerejupon" in Yoruba, "Aduro kokoo" or "Okramankote" in the Akan language in Ghana (Woode et al. [17]). Sphenocentrum jollyanum is widely used for medicinal purposes. The plant, mainly the bark, is used as an emetic and purgative, especially when poisoning is suspected (Akintobi et al. [14]). The root is used as an aphrodisiac tonic for men. The sap from chewing sticks made from the root is believed to relieve stomach-ache and constipation, and to boost appetite and sexual drive (Akintobi et al. [14]). Pounded roots are taken to treat high blood pressure (Alese et al. [15]). The boiled or pulped roots are given in draught or enema against epileptic fits (Akintobi et al. [14]). In Nigeria a decoction of the root is applied to dress tropical ulcers. A decoction of the leafy twigs is used as a wash to stop bleeding of wounds, sores and cuts. Powdered bark can also be used to cover the wounds (Akintobi et al. [14]). The fruit is edible and is taken against fatigue (Woode et al. [17]). 


\section{Aim and objectives}

This study was designed to evaluate effect of ethanol root-extract of Sphenocentrum jollyanum on some haematological parameters in Plasmodium berghei-infected mice.

\section{Materials and Methods}

\section{Materials}

Equipments, chemicals and reagents used were of analytical quality.

\section{Biological materials}

Albino mice and Sphenocentrum jollyanum roots were the biological materials used for this study. Fresh roots of Sphenocentrum jollyanum were collected from Aghara-oza Village in Izzi Local Government Area of Ebonyi State and were identified by a taxonomist in the Department of Applied Biology, Ebonyi State University, Abakaliki, Ebonyi State, Nigeria. The experimental animals that were used in this study were albino mice purchased from the Animal Unit of Faculty of Veterinary Medicine, University of Nigeria, Nsukka, Enugu, Nigeria. They were acclimatized for two weeks before the commencement of experiment in the Animal House of the Biochemistry Department, Ebonyi State University, Abakaliki, Ebonyi State, Nigeria.

\section{Preparation of ethanol root-extract of Sphenocentrum jollyanum}

The fresh plant material was washed and dried at a room temperature $\left(20-25^{\circ} \mathrm{C}\right)$ for the periods of two months and ground to coarse form using electrical blending machine properly sterilized. The coarse form was macerated in ethanol. The solution was allowed to stand for 2 days after which, the extract was filtered. The resulting extract was concentrated via evaporation by allowing it to stand overnight and then used for the study.

\section{Experimental design}

A total of thirty-six (36) albino mice were used for this study. The mice were randomly assigned into six (6) experimental groups of A, B, C, D, E and F with six (6) mice in each group. Group A (Normal control mice) were administered with normal saline and feed, group B (Positive control mice) were infected with Plasmodium berghei and were treated with $5 \mathrm{mg} / \mathrm{Kg}$ body weight of the standard drug, group C (Negative control mice) were infected with Plasmodium berghei without treatment, groups D, E 
and F were infected with Plasmodium berghei and treated orally with graded doses of 200,400 and $800 \mathrm{mg} / \mathrm{Kg}$ body weight of the extract of Sphenocentrum jollyanum root respectively.

\section{Induction of parasitaemia}

This was done according to the method described by Ugwu et al. [16].

\section{Determination of percentage parasitaemia count}

Determination of percentage parasitaemia $\left(\mathrm{Mp}^{+}\right)$was carried out according to the method of Dacie and Lewis [20].

\section{Determination of haematological parameters (PCV, HB, RBC and WBC)}

Determinations of haematological parameters were carried out according to the method of Dacie and Lewis [2].

\section{Statistical analysis}

This analysis was estimated using computer software known as Statistical Package for Social Sciences (SPSS), version 18. Mean values with different alphabets in the results are significantly different at $\mathrm{P}<0.05$.

\section{Result}

Effect of ethanol root extract of Sphenocentrum jollyanum on the body weight and percentage parasitaemia of Plasmodium berghei infected mice

The result showed variation of the body weight of mice during the last seven days of treatment with ethanol root extract of Sphenocentrum jollyanum. The result revealed that the weight of the treated mice increased while that of the untreated group decreased which showed that Plasmodium berghei reduced the body weight of the mice while ethanol root extract of Sphenocentrum jollyanum reversed the effect as shown in Figure 1. The treatment of Plasmodium berghei-infected mice with ethanol root extract of Sphenocentrum jollyanum at the doses of 200,400 and $800 \mathrm{mg} / \mathrm{Kg}$ body weight of the mice showed a significant $(\mathrm{P}<0.05)$ time and dose-dependent decrease in percentage parasitaemia count as shown in Figure 2. 


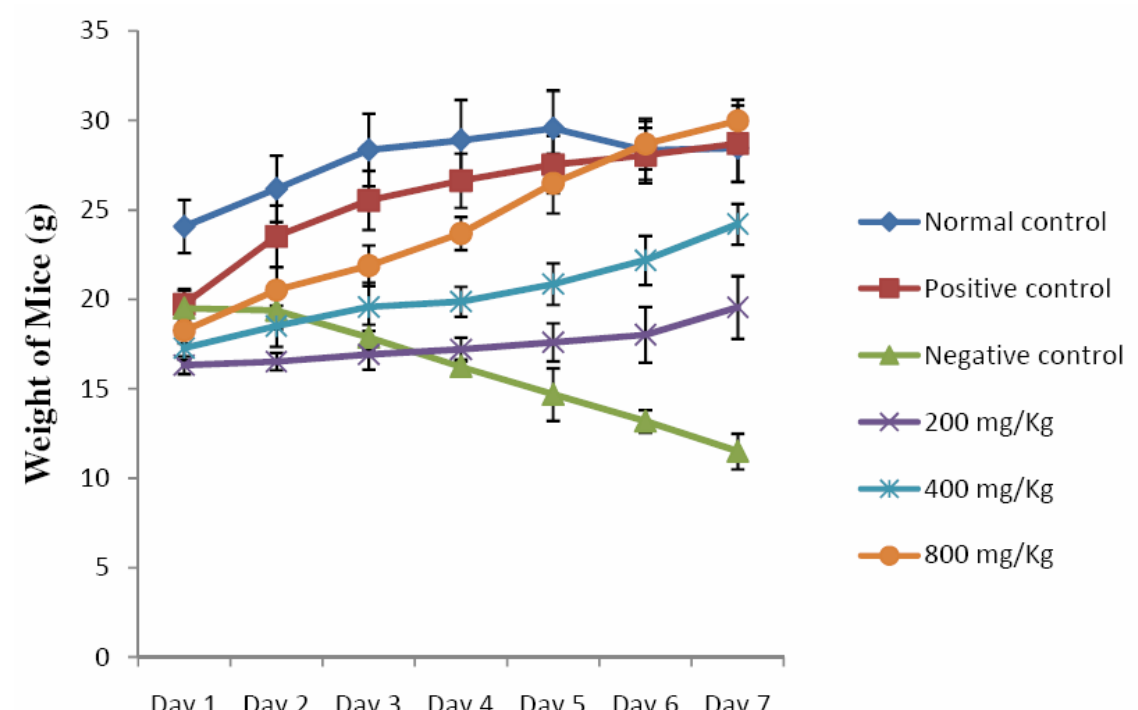

\section{Period (days)}

Figure 1. Weight of Plasmodium berghei-infected mice during the last seven (7) days of treatment with ethanol extract of Sphenocentrum jollyanum root.

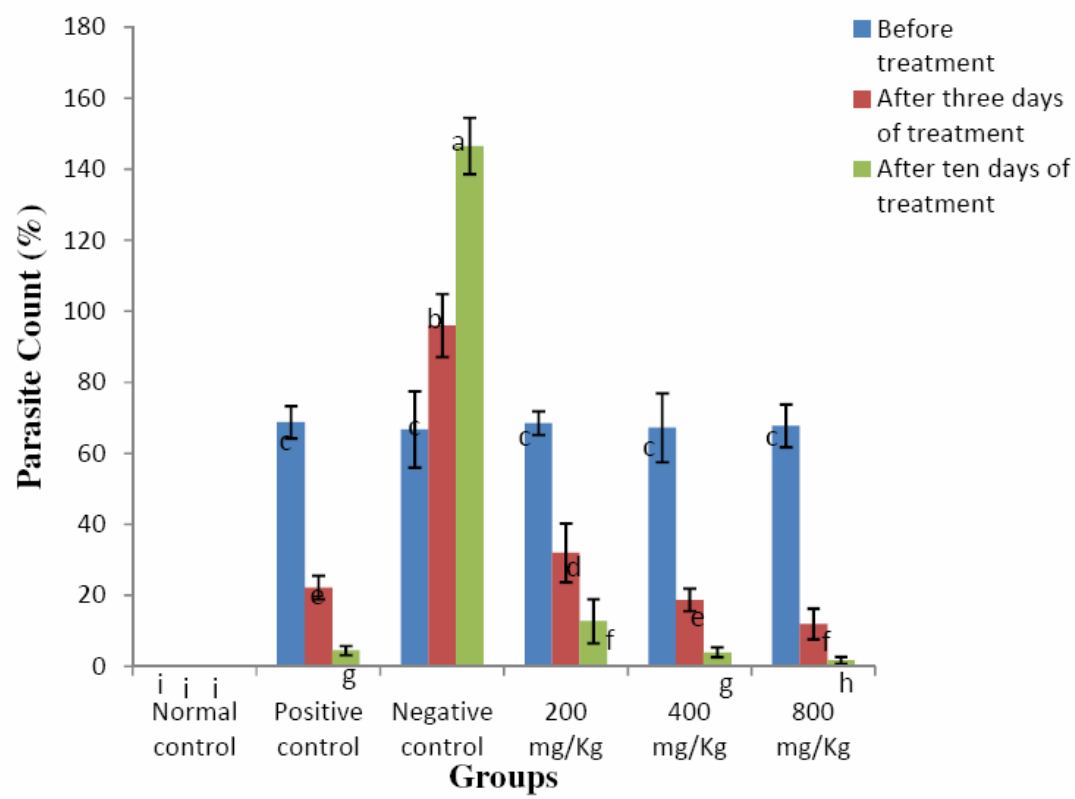

Figure 2. Parasite count in Plasmodium berghei-infected mice treated with ethanol extract of Sphenocentrum jollyanum root. 
Effect of ethanol root extract of Sphenocentrum jollyanum on the haematological parameters in Plasmodium berghei infected mice

Infection of the mice with $P$. berghei caused significant $(\mathrm{P}<0.05)$ decrease in the levels of PCV, HB, WBC and RBC relative to the normal control. However, treatment of the infected mice with the ethanol root extract of Sphenocentrum jollyanum at the doses of 200,400 and $800 \mathrm{mg} / \mathrm{Kg}$ body weight of the mice showed a significant $(\mathrm{P}<0.05)$ dose-dependent reversal in the trend of these parameters to a level comparable to the level observed among the positive control group. The effect of the extract, especially the highest dose of $800 \mathrm{mg} / \mathrm{Kg}$ body weight was comparable to that of the standard drug as there was no significant difference $(\mathrm{P}<0.05)$ between the groups.

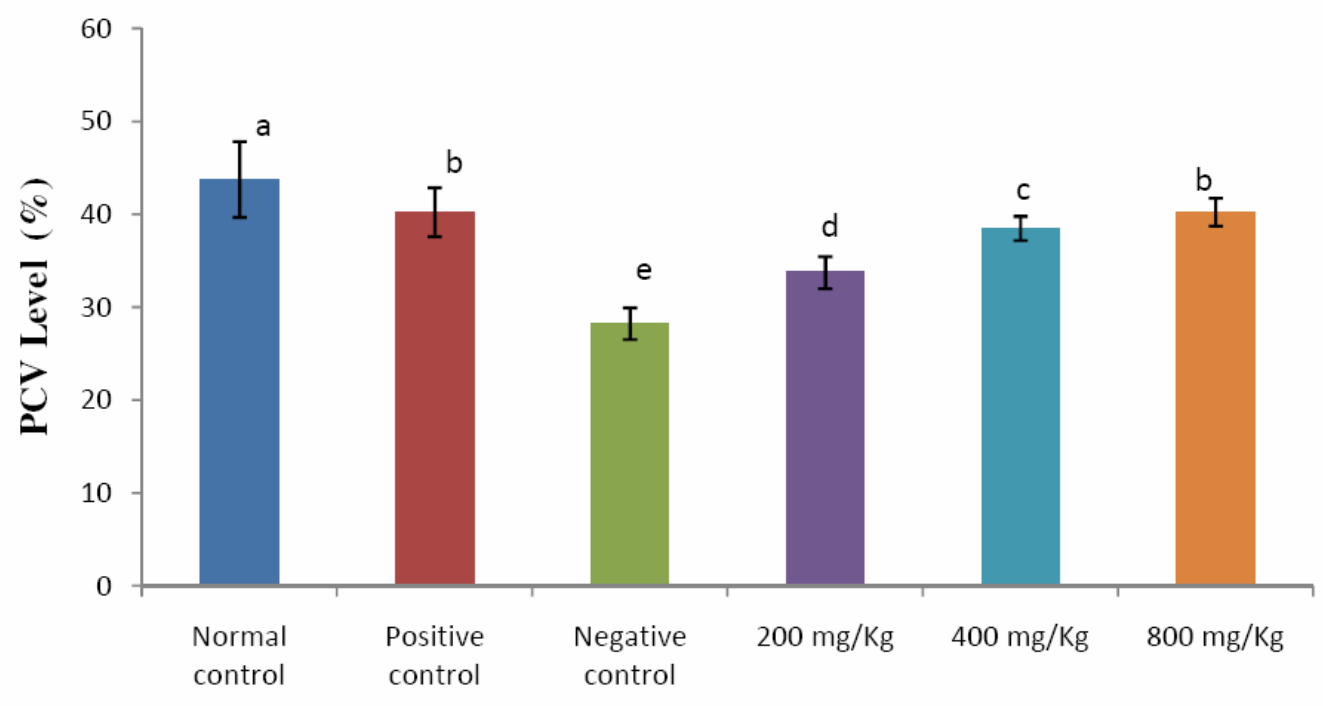

Groups

Figure 3. Pack cell volume level in Plasmodium berghei-infected mice treated with ethanol extract of Sphenocentrum jollyanum root. 


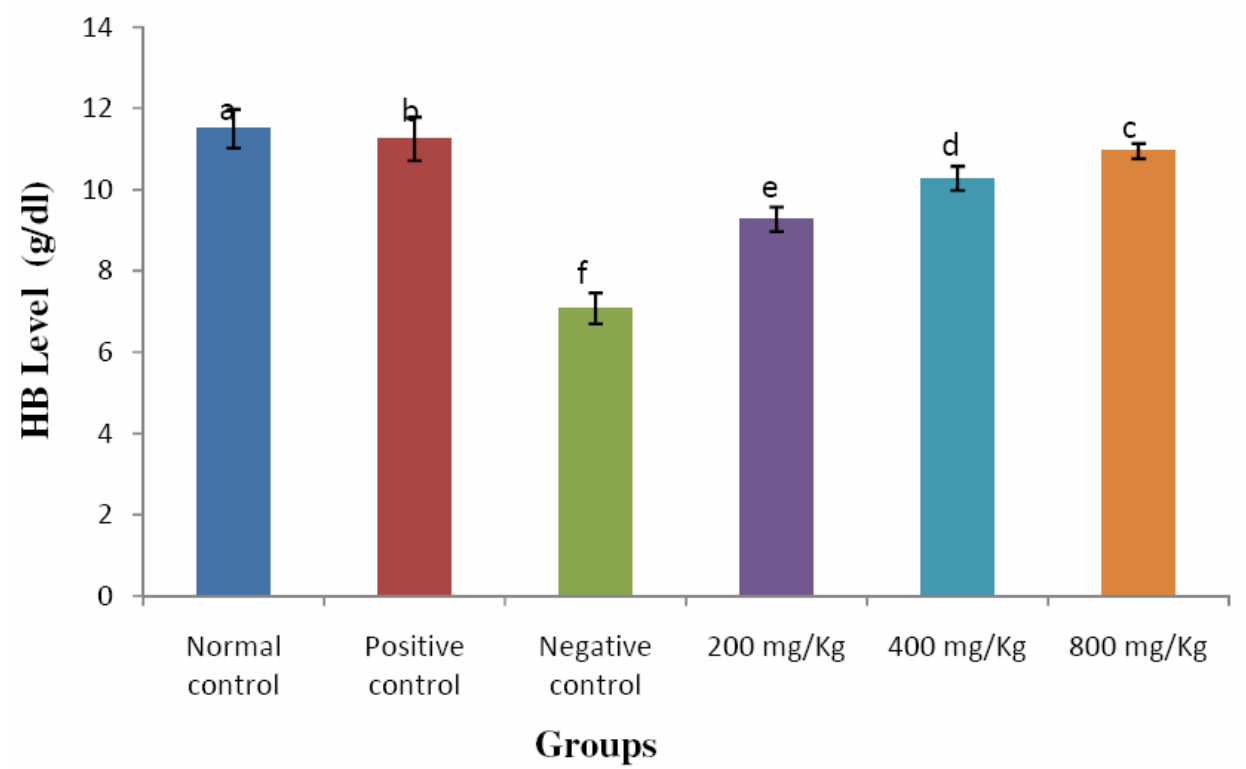

Figure 4. Haemoglobin level in Plasmodium berghei-infected mice treated with ethanol extract of Sphenocentrum jollyanum root.

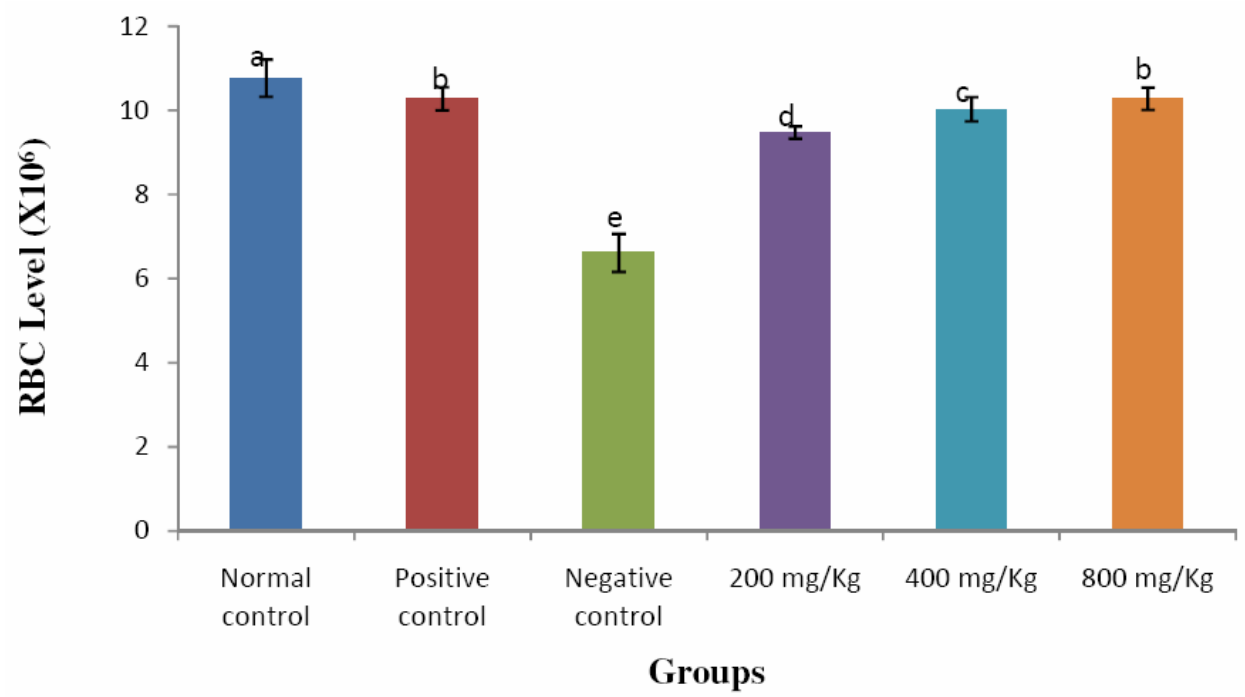

Figure 5. Red blood cell level in Plasmodium berghei-infected mice treated with ethanol extract of Sphenocentrum jollyanum root. 


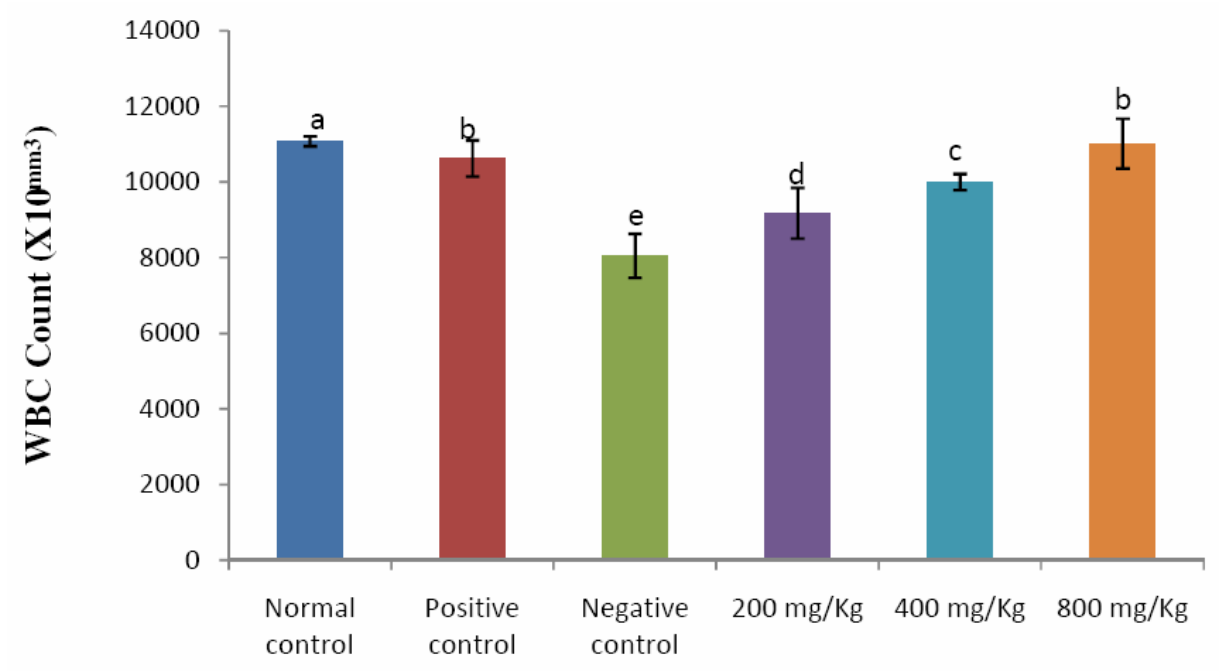

\section{Groups}

Figure 6. White blood cell level in Plasmodium berghei-infected mice treated with ethanol extract of Sphenocentrum jollyanum root.

\section{Discussion}

The results showed that infection of mice with Plasmodium berghei significantly $(\mathrm{P}<0.05)$ reduced the body weight relative to the level found in the normal control mice. But treatment of the infected mice with graded doses of Sphenocentrum jollyanum root extract significantly $(\mathrm{P}<0.05)$ restored the body weight in the animals in both time and dose dependent manner, with the effect of the highest dose being similar to that observed in the group treated with standard drug. This observation could be attributed to malaria infection. Infection of animals with malaria parasite leads to loss of weight due to loss of appetite or blood quality of the animals (Haruna et al. [18]), as well as generation of reactive oxygen species (ROS) by the parasites inside host erythrocytes (Iyawe and Onigbinde [19]). The gain in weight of animals treated with root extract of Sphenocentrum jollyanum may be attributed to the presence of some metabolites found in the plant that reduce the level of malaria parasite and thereby increase appetite of the animals. This findings correlates with the report by Mbaka et al. [21], which reported a significant $(\mathrm{P}<0.05)$ weight gain in both treated and control groups in the animals treated with extract of Sphenocentrum jollyanum leaves. This result also agrees with that of Uraku et al. [22] which reported general decrease in average body weight of the 
untreated mice on the 7th day relative to those treated with the leaf extracts of $S$. uliginosa, O. basilicum, $H$. spicigera and $C$. Citrates. By visual observation, the extract appeared to have stimulated the appetite of the mice thereby increasing the amount of food and water consumed and which might be responsible for increase in the body weight of the treated mice.

The results showed that infection of mice with Plasmodium berghei significantly $(\mathrm{P}<0.05)$ showed high percentage parasitaemia count relative to the normal control mice. But treatment of the infected mice with graded doses of Sphenocentrum jollyanum root extract significantly $(\mathrm{P}<0.05)$ reversed the effect in both time and dose dependent manner, with the effect of the highest dose being similar to that observed in the group treated with standard drug. The presence of the parasite alone in the blood does not induce disorder, but the response of the host immune system against foreign autogenic organism via free radical generation, activation of phospholipase cascade series and generation of prostaglandins and other haemolytic principles such as free fatty acids does (Salawu et al. [23]). The reduction in the percentage parasitaemia may be due to effect of the extract on the parasites-plasmodium level (Odeghe et al. [24]). This result correlates with the findings of Olorunnisola and Afolayan [25] which reported that leaf extract of Sphenocentrum jollyanum exhibits a significant $(\mathrm{P}<0.05)$ dose dependant anti-plasmodial activities. The results also agree with those of Uraku et al. [22] which reported a significant $(\mathrm{P}<0.05)$ daily increase in the level of parasitaemia in the parasitized untreated groups and a significant $(\mathrm{P}<0.05)$ dose dependent decrease in the level of parasitaemia in the parasitized groups treated with varying doses of the various medicinal plants (Spilanthes uliginosa, Ocimum basilicum (Sweet Basil), Hyptis spicigera and Cymbopogon citrates) and the standard drug.

The result on haematological markers showed that PCV, HB, WBC and RBC levels were significantly $(\mathrm{P}<0.05)$ low in the Plasmodium berghei-infected mice relative to the normal control mice. Treatment of Plasmodium berghei-infected mice with $5 \mathrm{mg} / \mathrm{Kg}$ standard drug and ethanol root extract of Sphenocentrum jollyanum at the doses of 200 , 400 and $800 \mathrm{mg} / \mathrm{Kg}$ body weight of the mice significantly $(\mathrm{P}<0.05)$ reversed the levels of this these parameters in a dose dependent manner to a level similar to that of the normal control. The effect of the extract, especially, the highest dose of $800 \mathrm{mg} / \mathrm{Kg}$ body weight was comparable to that of the standard drug as there was no significant $(\mathrm{P}<0.05)$ difference between these parameters found in these groups. These suggest that the root 
extract may have the potential to stimulate erythropoietin release in the kidney known to enhance RBC production (erythropoiesis) (Polenakovic and Sikole [26], Sanchez-Eisner et al. [27]). This work agrees with the work of Odeghe et al. [24] which reported that Plasmodium berghei-infected mice treated with extract of Anthocleista grandiflora stem bark had significant $(\mathrm{P}<0.05)$ effect on PCV, Hb, WBC and platelet count from day 3 to day 14 when compared with the control. Our results also agrees with the report of Mbaka et al. [21] which stated that different parts of Sphenocentrum jollyanum plant enhances erythropoiesis and therefore could be used as haematinic agent. Also Mbaka and Owolabi [28], reported that extract of Sphenocentrum jollyanum seed significantly increased $(\mathrm{P}<0.05) \mathrm{RBC}$, packed cell volume $(\mathrm{PCV})$ and haemoglobin count $(\mathrm{Hb})$.

However, our findings disagrees with that of Amidu et al. [29] which reported that there were no significant $(\mathrm{P}>0.05)$ differences found in most of the haematological parameters in rats administered with the extract of Sphenocentrum jollyanum leaves. This variation in the results could be as a result of different locations in which the plants were collected or may be attributed to the part or species of the plant used. This variation may equally be attributed to the methodology, experimental model or doses of the extracts used. In conclusion, this study indicates that ethanol root-extract of Sphenocentrum jollyanum contain bioactive compounds which could be used in the management of anaemic diseases associated with Plasmodium berghei infection.

This study indicates that ethanol root-extract of Sphenocentrum jollyanum could be used in the management of anaemic diseases associated with Plasmodium berghei infection.

\section{References}

[1] A. Oehadian, H. Suryadinata, S. Dewi, R. Pramudyo and B. Alisjahbana, The role of neutrophyl lymphocyte count ratio as an inflammatory marker in systemic lupus erythematosus, Acta Medical Indonesia 45 (2013), 170-174.

[2] M. Merck, Haematologic Reference Ranges, 2nd ed., Mareck Veterinary Manual, 2012, pp. 45-50.

[3] C. O. Olafedehan, A. M. Obun, M. K. Yusuf, O. O. Adewumi, A. O. Olafedehan, A. O. Awofolaji and A. A. Adeniji, Effects of residual cyanide in processed cassava peel meals on haematological and biochemical indices in growing rabbits, Proceedings of 35th Annual Conference of Nigerian Society for Animal Production (2010), 212-214. 
[4] L. J. Isaac, G. Abah, B. Akpan and I. U. Ekaette, Haematological properties of different breeds and sexes of rabbits, Proceedings of the 18th Annual Conference of Animal Science Association of Nigeria (2013), 24-27.

[5] B. Qin, N. Ma, Q. Tang, T. Wei, M. Yang, H. Fu, Z. Hu, Y. Liang, Z. Yang and R. Zhong, Neutrophil to lymphocyte ratio (NLR) and platelet to lymphocyte ratio (PLR) were useful markers in assessment of inflammatory response and disease activity in SLE patients, Mode Rheumatology 26 (2016), 372-376.

https://doi.org/10.3109/14397595.2015.1091136

[6] S. Soydinc, I. H. Turkbeyler, Y. Pehlivan, G. Soylu, M. F. Goktepe, M. Bilici, O. Zengin, B. Kisacik and A. M. Onat, Mean platelet volume seems to be a valuable marker in patients with systemic sclerosis, Inflammation 37 (2014), 100-106.

https://doi.org/10.1007/s10753-013-9716-x

[7] P. Mason, Haematological approach, The Pharmacological Journal 272 (2004), 88-255.

[8] A. Maton, H. Jean, W. M. Charles, J. Susan, Q. W. Maryanna, L. David and D. Jill, Human Biology and Health, Englewood Cliffs, 1st ed., New Jersey, USA: Prentice Hall, 1993, pp. 45-59.

[9] W. K. Purves, S. David, H. Gordon, H. Orians and H. Craig, Life: The Science of Biology, 7th ed., Sunderland, Mass: Sinauer Associates, 2004, p. 954.

[10] A. Bruce, Leukocyte functions and percentage breakdown, in: Molecular Biology of the Cell, NCBI Bookshelf, Sweden, 2005, p. 67.

[11] H. P. Range, M. M. Dale, J. M. Ritter and P. K. Moore, Pharmacology, 5th ed., Churchill Livingstone, Edinburgh, 2003, pp. 210-319.

[12] F. Pierigè, S. Serafini, L. Rossi and M. Magnani, Cell-based drug delivery, Advanced Drug Delivery Reviews 60(2) (2008), 286-295.

https://doi.org/10.1016/j.addr.2007.08.029

[13] R. Nia, D. H. Paper, E. E. Essien, K. C. Iyadi, A. I. L. Bassey, A. B. Antai and G. Franz, Evaluation of the anti-oxidant and anti-angiogenic effects of Sphenocentrum jollyanum, African Journal of Biomedical Research 7 (2004), 129-132.

https://doi.org/10.4314/ajbr.v7i3.54169

[14] O. A. Akintobi, A. O. Adejuwon, B. A. Bamkefa, O. V. C. Daniels and V. O. Ojo, Antimicrobial potency of Sphenocentrum jollyanum on some human pathogenic bacteria, Academia Arena 5(5) (2013), 1-7.

[15] M. O. Alese, O. S. Adewole, O. M. Ijomone, S. A. Ajayi and O. O. Alese, Hypoglycemic 
and hypolipidemic activities of methanolic extract of Sphenocentrum jollyanum on streptozotocin-induced diabetic wistar rats, European Journal of Medicinal Plants 4(3) (2014), 353-364. https://doi.org/10.9734/EJMP/2014/7618

[16] O. P. C. Ugwu, O. F. C. Nwodo, P. E. Joshua, C. E. Odo, A. Bawa, E. C. Ossai and C. C. Adonu, Anti-malaria and hematological analyses of ethanol extract of Moringa oleifera leaf on malaria infected mice, International Journal of Pharmacy and Biological Sciences 3(1) (2013), 360-371.

[17] E. Woode, N. Amidu, William K. B. A. Owiredu, E. Boakye-Gyasi, E. F. Laing, C. Ansah and M. Duwiejua, Anxiogenic-like effects of root extract of Sphenocentrum jollyanum Pierre in murine behavioral models, Journal of Phamacology and Toxicology 4(3) (2009), 91-106. https://doi.org/10.3923/jpt.2009.91.106

[18] Y. Haruna, H. O. Kwanashie, J. A. Anuka, S. E. Atawodi and I. M. Hussaimi, In vivo anti-malarial activity of methanol root extract of Securidaca longepedunculata in mice infected with Plasmodium berghei, International Journal of Modern Biology and Medicine 3(1) (2013), 7-16.

[19] H. O. T. Iyawe and A. O. Onigbinde, Effect of an antimalarial and a micronutrient supplementation on respiration-induced oxidative stress, Pakistan Journal of Nutrition 3(6) (2004), 318-321. https://doi.org/10.3923/pjn.2004.318.321

[20] J. V. Dacie and S. M. Lewis, Practical Heamatology, 7th ed., ELBS with Churchill Livingstone: Longman Group, UK, Ltd., 2000, 837-852.

[21] G. O. Mbaka, O. O. Adeyemi and A. A. Oremosu, Acute and sub-chronic toxicity studies of the ethanol extract of the leaves of Sphenocentrum jollyanum (Menispermaceae), Agriculture and Biology Journal of North America 1(3) (2010), 265-272. https://doi.org/10.5251/abjna.2010.1.3.265.272

[22] A. J. Uraku, A. N. C. Okaka, U. A. Ibiam, K. N. Agbafor, N. A. Obasi, P. M. Ajah, O. U. Obasi and F. N. Nwalo, Antiplasmodial activity of ethanolic leaf extracts of Spilanthes uliginosa, Ocimum basilicum (Sweet Basil), Hyptis spicigera and Cymbopogon citratus on mice exposed to Plasmodium berghei Nk 65, International Journal of Biochemistry Research and Review 6(1) (2015), 28-36. https://doi.org/10.9734/IJBCRR/2015/9806

[23] O. A. Salawu, A. Y. Tijani, H. Babayi, A. C. Nwaeze, R. A. Anagbogu and V. A. Agbakwuru, Anti-malarial activity of ethanolic stem bark extract of Faidherbia Albida (Del) a. Chev (Mimosoidae) in mice, Archives of Applied Science Research 2(5) (2010), 261-268.

[24] O. B. Odeghe, A. A. Uwakwe and C. C. Monago, Antiplasmodial activity of methanolic 
stem bark extract of Anthocleista grandiflora in mice, International Journal of Applied Science and Technology 2(4) (2012), 142-148.

[25] O. S. Olorunnisola and A. J. Afolayan, In vivo anti-malaria activity of methanolic leaf and root extracts of Sphenocentrum jollyanum Pierre, African Journal of Pharmacy and Pharmacology 5(14) (2011), 1669-1673. https://doi.org/10.5897/AJPP11.117

[26] M. Polenakovic and T. Sikole, Is erythropoietin a survival factor for red blood cells?, Journal of American Society of Nephrology 7 (1996), 1178-1182.

[27] T. Sanchez-Elsner, J. R. Ramirez, F. Rodriguez-Sanz, E. Varela, C. Bernabeu and L. M. Botella, A cross-talk between hypoxia and TGF- $\beta$ orchestrates erythropoietin gene regulation through SP1 and Smads, Journal of Molecular Biology 336 (2004), 9-24. https://doi.org/10.1016/j.jmb.2003.12.023

[28] G. O. Mbaka and M. A. Owolabi, Evaluation of haematinic activity and subchronic toxicity of Sphenocentrum jollyanum (Menispermaceae) seed oil, European Journal of Medicinal Plants 1(4) (2011), 140-152. https://doi.org/10.9734/EJMP/2011/333

[29] N. Amidu, E. Woode, William K. B. A. Owiredu, A. A. George, B. A. Kofi and C. Opoku-Okrah, An evaluation of toxicity and mutagenicity of Sphenocentrum jollyanum, International Journal of Pharmacology 4 (2008), 67-77.

https://doi.org/10.3923/ijp.2008.67.77 